\title{
"Basta ya!": Aesthetic Calibanism and Cold War-Era Context in the Protest Songs of Atahualpa Yupanqui
}

\author{
JULIUS REDER CARLSON
}

\begin{abstract}
Using the song "Basta ya!" ("Enough Already!") as a point of departure, this article supplements the emerging literature on Argentine singer-songwriter Atahualpa Yupanqui's protest songs, emphasizing the importance of musical sound in their appeal to political activists and reinforcing the role of Cold War-era contextual factors in shaping their meanings. Like "Basta ya!," it argues, many of Yupanqui's protest songs are characterized by "aesthetic calibanism," a lyrical and musical style that, embodying the marginalized and the oppressed, transforms mainstream, often socially conservative, representations of Latin American identity into what can be heard as statements of "revolutionary" political resistance. Championed by the Communist Party and the Nueva Canción (New Song) movement and suppressed by reactionary states and multinational record companies, these songs became iconic for the "internationalist singing left" while remaining absent from large sectors of the Argentine public sphere.
\end{abstract}

In 1971, the Argentine singer-songwriter Atahualpa Yupanqui (1908-1992) re-recorded "Basta ya!," an "anti-imperialist song" that he had first recorded two decades earlier, in 1950. ${ }^{1}$ By any definition, the 1971 version of "Basta ya!" is a protest song. ${ }^{2}$ In the first three stanzas, Yupanqui sings in the voice of an exploited carter, describing the travails of his workday. In the final four, he decries social inequality, augurs the liberation of the Latin American working class, and denounces the Vietnam War. The guitar accompaniment to Yupanqui's lyric plays a powerful role in shaping its affective meaning. Following a guitar prelude evocative of setting and action, the initial, mournful verses of the song are in a plodding D minor with somber b6 $\rightarrow 5$ gestures and a plaintive vocal melody. The ensuing denunciatory verses are accompanied by a rousing, D major march: "Enough already!" cries Yupanqui, reinforcing the violent tenor of his demand with an explosion of strumming.

Songs like "Basta ya!" reinforce a growing body of scholarship that portrays Atahualpa Yupanqui as a musical activist, a singer-songwriter who pioneered Argentine protest song. Drawing on a corpus of

\footnotetext{
1 "Basta ya!" appears with the subtitle "an anti-imperialist song from Puerto Rico" in a Romanian concert program from 1950. Yupanqui's correspondence indicates that he also used the epithet at this time. See Schubert Flores and Héctor García Martínez, Hombres y caminos: Yupanqui afiliado comunista (Buenos Aires: Editorial Fundación Ross, 2012), 455 and Víctor Pintos, ed. Cartas a Nenette (Buenos Aires: Editorial Sudamericana, 2001), 67.

${ }^{2}$ For contemporary Latin American perspectives on the definition of protest song, see: Marita Fornaro and Fabricia Malán, "Protesta, siempre: una panorama y tres casos uruguayos," Boletín Música, no. 45 (2017), 41-71 and Carlos Molinero and Pablo Vila, "Introduction," in The Militant Song Movement in Latin America: Chile, Uruguay, and Argentina, ed. Pablo Vila (New York: Lexington Books, 2015), 1-19.
} 
approximately two dozen compositions written and recorded over the course of Yupanqui's career, ${ }^{3}$ this academic literature is dominated by lyrical analysis: Yupanqui's poetry is interpreted to embody the experiences of workers and indigenous peoples and, largely through the description of social injustice, to constitute a form of political critique. ${ }^{4}$ Recent historiography regarding Yupanqui's mid-century affiliation with the Communist Party, along with portions of a vast biographical hagiography, complement these hermeneutic exercises, showing Yupanqui to have been both politically aware and politically engaged, especially during the late 1940s and early 1950s. ${ }^{5}$

In this article, I use "Basta ya!" as a point of departure for supplementing the emerging literature on Atahualpa Yupanqui's protest songs, appending an exploration of their musical sound to a discussion of their lyrical content and reinforcing the role of Cold War-era contextual factors in shaping their meanings. This fusion of textual and contextual analysis engages with two conversations central to scholarship on the genre of protest music. First, it reaffirms Simon Frith's observation that protest songs tend to communicate musical feelings more powerfully than lyrical ideas, ${ }^{6}$ suggesting that the sound of Yupanqui's compositions is as central to their political connotations as their poetic texts. ${ }^{7}$ Second, it both ascribes to and expands the methodological contentions of protest music scholars like David Spener ${ }^{8}$ and Ron Eyerman and Andrew Jameson, ${ }^{9}$ engaging not only with the ways in which Yupanqui's music has acquired meaning through its use by the "internationalist singing left," ${ }^{10}$ but also the factors that have contributed to

\footnotetext{
${ }^{3}$ Yupanqui-authored compositions associated with "protest" include (in alphabetical order): "El arriero va," "Basta ya!," "Campesino," "Camino del indio," "Canción de cañaveral," "Canción del pampino," "Duerme negrito," "Guitarra dímelo tú," "Los hermanos," "Juan," "Le tengo rabia al silencio," "Minero soy” ("Baguala de los mineros"), "El payador perseguido," "Piedra y camino," "El pintor," "Preguntitas sobre Dios," "La pobrecita," "El poeta," "Trabajo, quiero trabajo," and

"Zambita de los pobres." These and other songs represent less than 10 percent of the singer-songwriter's total creative output, although they are some of the most iconic for contemporary audiences.

${ }^{4}$ Eliana E. Abdala, La poesía de Atahualpa Yupanqui (Buenos Aires: Corregidor, 2016); Ricardo Kaliman, Alhajita es tu canto: El capital simbólico de Atahualpa Yupanqui (Córdoba: Editorial Comunicarte, 2004); Carlos Molinero and Pablo Vila, "Atahualpa Yupanqui: The Latin American Precursor of the Militant Song Movement," in The Militant Song Movement in Latin America: Chile, Uruguay, and Argentina, ed. Pablo Vila (New York: Lexington Books, 2015), $163-193$.

${ }^{5}$ Schubert Flores and Héctor García Martínez, Hombres y caminos: Yupanqui, afiliado comunista (Córdoba, Argentina: Editorial Fundación Ross, 2012); Norberto Galasso, Atahualpa Yupanqui: El canto de la patria profunda, 4th ed. (Buenos Aires: Ediciones del Pensamiento Nacional, 2013); Félix Luna, Atahualpa Yupanqui (Madrid: Ediciones Jucar, 1974); Fabiola Orquera, "From the Andes to Paris: Atahualpa Yupanqui, the Communist Party, and the Latin American Folksong Movement," in Red Strains: Music and Communism Outside the Communist Bloc, ed. Robert Adlington (Oxford, UK: Oxford University Press, 2013), 105-119, https://doi.org/10.5871/bacad/9780197265390.003.0009; Fabiola Orquera, "Marxismo, peronismo, indocriollismo: Atahualpa Yupanqui y el norte argentino," Studies in Latin American Popular Culture 27 (2008), 1-21; Sergio Pujol, En nombre del folclore (Buenos Aires: Emecé Editores, 2008); Manuel Urtizberea, Don Ata: La voz de un continente (Buenos Aires: Editorial Marea, 2017).

${ }^{6}$ Frith's argument rearticulates the findings of 1970s sociologists who discovered that only a small proportion of listeners could accurately repeat the lyrics of protest songs. See R. Serge Denissoff and Richard A. Peterson, eds., The Sounds of Social Change (Chicago, IL: Rand McNally Sociology Series, 1972) and Simon Frith, Performing Rites: On the Value of Popular Music (Cambridge, MA: Harvard University Press, 1996), 158-202.

${ }^{7} \mathrm{My}$ intention is not to claim that there is a mechanistic connection between music and meaning but rather that text and context cannot be abstracted from one another. As Robert Walser writes: "Like genres and discourses, musical meanings are contingent but never arbitrary. There is never any essential correspondence between particular musical signs or processes and specific social meanings, yet such signs and processes would never circulate if they did not produce such meanings.” Robert Walser, Running with the Devil (Middletown, CT: Wesleyan University Press, 1993), 29.

${ }^{8}$ David Spener, We Shall Not Be Moved/No nos moverán (Philadelphia: Temple University Press, 2016), https://doi.org/10.26530/OAPEN 605458.

${ }^{9}$ Ron Eyerman and Andrew Jamison, Music and Social Movements: Mobilizing Traditions in the Twentieth Century (Cambridge, UK: Cambridge University Press, 1998), https://doi.org/10.1017/CBO9780511628139.

${ }^{10}$ David Spener uses this term to refer to the transnational networks of individuals and communities that used song as a resource for political activism over the course of the twentieth century.
} 
its suppression by state and commercial actors in the Argentine public sphere. ${ }^{11}$

The article comprises two sections. In the first section, I use "Basta ya!" as a representative case study, identifying an "aesthetic calibanism" common to both the lyrics and the music of this iconic song and sketching a reception history that highlights the Cold War-era processes of politicization and erasure that have shaped its meanings over time. In the second section, I apply my observations to a selection of other Atahualpa Yupanqui-authored protest songs, demonstrating the role of aesthetic calibanism and political context in shaping a corpus of musical texts with lyrical and musical content that is at times markedly different than "Basta ya!".

\section{The aesthetic calibanism of "Basta ya!"}

I commence by exploring what I call the "aesthetic calibanism" of "Basta ya!," appending an analysis of the lyrical content of Atahualpa Yupanqui's protest song with an exploration of its musical sound. A reworking of Nico Saquito y Los Guaracheros de Oriente's “Al vaivén de mi carreta” (1950), "Basta ya!" transforms a popular dance tune into a politicized embodiment of an oppressed worker. Beginning with a brief exploration of Yupanqui's lyrical modifications to "Al vaivén de mi carreta," the following hermeneutic exercise outlines the way in which this singer-songwriter's embrace of solo performance, defamiliarization of dance genre conventions, and rejection of musical "professionalism" contribute to effecting this semantic change.

Intentionally political, my use of the word calibanism to describe Atahualpa Yupanqui's reworkings of songs like "Al vaivén de mi carreta" alludes to Cuban intellectual Roberto Fernández Retamar's "revolutionary" reading of Shakespeare's Caliban as a Latin American cultural insurgent ${ }^{13}$-an autochthonous, proletarian figure that, in contrast to the loyal servant Ariel, rejected imperialist hegemony and reclaimed local identity, using the language of his oppressor, Prospero, in order to curse him. ${ }^{14}$ Foregrounding the cultural cannibalism implicit in Fernández Retamar's metaphor, I use the phrase "aesthetic calibanism" to describe the ways in which Yupanqui's protest songs rework mainstream, often socially conservative, Latin American representations of selfhood, transforming them into embodiments of the marginalized and the oppressed ripe for interpretation as statements of "revolutionary" political resistance. $^{15}$

\footnotetext{
${ }^{11}$ See Fernando Reyes Matta for a brief discussion of this phenomenon as it pertained to the Nueva Canción. Fernando Reyes Matta, "The New Song and Its Confrontation in Latin America," in Marxism and the Interpretation of Culture, ed. Cary Nelson and Lawrence Grossberg (Urbana and Chicago, IL: University of Illinois Press, 1988), 447-460, https://doi.org/10.1007/978-1-349-19059-132.

${ }^{12} 1950$ refers to the date of the recording analyzed in this article. Nico Saquito wrote the song in 1936.

${ }^{13}$ Fernández Retamar first outlined his politicized interpretation of Caliban in the 1971 essay "Caliban: Notes Toward a Discussion of Culture in Our America." See Alden Vaughan and Virginia Vaughan for a summary of the Caliban trope in Latin American literature. Roberto Fernández Retamar, "Caliban: Notes Toward a Discussion of Culture in Our America" in Caliban and Other Essays, trans. Edward Baker (Minneapolis: University of Minnesota, 1989), 3-46; Alden Vaughan and Virginia Mason Vaughan, Shakespeare's Caliban. A Cultural History (New York: Cambridge University Press, 1991).

${ }^{14}$ As Caliban tells his master Prospero: "You taught me language; and my profit on't/ Is, I know how to curse. The red plague rid you/ For learning me your language!"

${ }^{15}$ It could be argued that, like the Brazilian anthropophagists, Fernández Retamar advocated the cannibalization of colonial (European) and imperialist (North American) culture. In this article, I interpret him to champion a "revolutionary" use of a mestizo Latin American tradition with multiple political potentialities, including use by the forces of internal colonialism (i.e. Prospero's loyal servant, Ariel). That Latin American culture could be as much of a vehicle for the legitimization and naturalization of social inequality as its European and North American counterparts is exemplified by the Argentine "Native" music explored in the second half of this article, much of which was associated with — and championed by — the local landholding elite. Yupanqui's aesthetic reworking of this music, I argue, allowed it to be used to "curse" the unjust
} 
The aesthetic calibanism of "Basta ya!" is most immediately evident in Yupanqui's reworking of Nico Saquito's lyrics (see figure 1). Chronicling the arduous workday of a sugarcane carter, the lyrics to "Al vaivén de mi carreta," depict the suffering of a rural worker who, "knowing that his life is a punishment . . . cheers himself with his songs." ${ }^{16}$ Yupanqui's "Basta ya!" transforms this message of fatalistic resignation into a call for revolutionary action. Borrowing the stanzas of "Al vaivén de mi carreta" that recount the carter's travails and the exploitative practices of his anonymous British boss (verses 1, 3, and 4), Yupanqui discards the fatalism of Nico Saquito's second verse and the resignation of his bridge, replacing them with quatrains that denounce the economic dominance of the United States (verse 4), suggest that the workers of Mexico and Panama will soon be liberated from "slavery" (verse 5), identify the sugarcane carter as a "revolutionary" (verse 6), and intimate the victory of the Viet Cong over the US military (verse 7). ${ }^{17}$ The ultimate effect is to both radicalize and globalize Saquito's lyrical message. While Saquito's carter is a poor brute resigned to his plight, Yupanqui's worker is a symbol of international resistance. While Saquito's song is intended to lighten the load, Yupanqui's is a revolutionary act.

\begin{tabular}{|c|c|}
\hline $\begin{array}{l}\text { "Al vaivén de mi carreta” (1950) } \\
\text { Ñico Saquito y los Guaracheros de Oriente }\end{array}$ & $\begin{array}{l}\text { "Basta ya!" (1971) } \\
\text { Atahualpa Yupanqui }\end{array}$ \\
\hline $\begin{array}{l}\text { Verse } 1 \\
\text { Eh! Se acerca la madrugada } \\
\text { Los gallos ya están cantando } \\
\text { Compadre, están anunciando } \\
\text { Que ya empieza la jornada, bien }\end{array}$ & $\begin{array}{l}\text { Verse } 1 \\
\text { Ay! Ya viene la madrugada } \\
\text { Los gallos están cantando } \\
\text { Compadre, están anunciando } \\
\text { Que ya empieza la jornada }\end{array}$ \\
\hline $\begin{array}{l}\text { Verse } 2 \\
\text { Eh! Entra el año y sale el año } \\
\text { Trabajo de sol a sol } \\
\text { Y cada día estoy peor } \\
\text { Compadre, que desengaño, bien }\end{array}$ & $\begin{array}{l}\text { Verse } 2 \\
\text { Ay! Al vaivén de mi carreta } \\
\text { Nació esta lamentación } \\
\text { Compadre ponga atención } \\
\text { Que ya empieza mi cuarteta } \\
\text { No tenemos protección }\end{array}$ \\
\hline $\begin{array}{l}\text { Verse } 3 \\
\text { Eh! Trabajo pa' el inglés } \\
\text { El destino traicionero } \\
\text { Su mundo por un dinero } \\
\text { En la mano no se ve, ya ves }\end{array}$ & $\begin{array}{l}\text { Verse } 3 \\
\text { Ay! Trabajo para el inglés } \\
\text { Trabajo de carretero } \\
\text { Sudando por un dinero } \\
\text { Que en la mano no se ve }\end{array}$ \\
\hline $\begin{array}{l}\text { Verse } 4 \\
\text { Eh! Al vaivén de mi carreta } \\
\text { Nació esta lamentación } \\
\text { Compayo oiga mi cuarteta } \\
\text { No tenemos protección }\end{array}$ & $\begin{array}{l}\text { Verse } 4 \\
\text { El yanqui vive en palacio } \\
\text { Yo vivo en un barracón } \\
\text { Cómo es posible que viva } \\
\text { El yanqui mejor que yo? }\end{array}$ \\
\hline
\end{tabular}

Figure 1: Comparison of the lyrics to "Al vaivén de mi carreta" and "Basta ya!"

social order that it had previously contributed to reifying.

16 "Sabiendo que su vida es un destierro/ se alegra con sus cantares." Although he recites a long list of grievances, including long working hours and low pay, Nico Saquito's singer is ultimately fatalistic. His wish is not for a better world (which he seems unable to imagine) but rather for the end of the workday.

${ }^{17}$ This final verse was added in 1971. 


\begin{tabular}{|c|c|}
\hline \multirow[t]{3}{*}{$\begin{array}{l}\text { Verse } 5 \text { (bridge) } \\
\text { Triste vida la del carretero } \\
\text { Que anda por esos cañaverales } \\
\text { Siempre lucha el pobre resignado } \\
\text { Por vencer a los crudos pantanales } \\
\text { Sabiendo que su vida es un destierro } \\
\text { Se alegra con sus cantares }\end{array}$} & $\begin{array}{l}\text { Verse } 5 \\
\text { Que pasa con mis hermanos } \\
\text { De México y Panamá? } \\
\text { Sus padres fueron esclavos } \\
\text { Sus hijos no lo serán }\end{array}$ \\
\hline & $\begin{array}{l}\text { Verse } 6 \\
\text { Yo de pequeño aprendí } \\
\text { A luchar por esa paz } \\
\text { De grande lo repetí } \\
\text { Y a la cárcel fui a parar }\end{array}$ \\
\hline & $\begin{array}{l}\text { Verse } 7 \\
\text { Quién a ganado la guerra } \\
\text { En los montes del Vietnam? } \\
\text { El guerrillero en su tierra } \\
\text { Y el yanqui en el cinema }\end{array}$ \\
\hline $\begin{array}{l}\text { Chorus } \\
\text { Cuándo llegaré? Cuándo llegaré al bohío? } \\
\text { Cuándo llegaré? Cuándo llegaré al bohío? }\end{array}$ & $\begin{array}{l}\text { Chorus } \\
\text { Basta ya! Basta ya! } \\
\text { Basta ya que el yanqui mande! }\end{array}$ \\
\hline
\end{tabular}

Figure 1: (cont.)

The lyrical calibanism effected by Atahualpa Yupanqui in "Basta ya!" is accompanied by a parallel musical transformation of "Al vaivén de mi carreta." Replacing the song's formally determined alternation of melodic and harmonic sections with an organic, bipartite structure closely related to lyrical meaning, Yupanqui's 1950 version of "Basta ya!" pairs the travails of the sugarcane worker with a lugubrious, minormode accompaniment and the "revolutionary" choruses with an upbeat melody in the parallel major. ${ }^{18}$ In his 1971 version of the tune, meanwhile, Yupanqui builds on this foundation with a series of elaborate riffs. In a guitar introduction that might be better understood as a kind of diminutive prelude, virtuosic instrumental solos are replaced with gestures representing lyrical affect, context, and subject. A b6 $\rightarrow 5$ "weeping" motive sets the gloomy emotional scene, son syncopations suggest a "Caribbean" locale, and a trudging, toil-like bass riff provides a brief portrait of the exploited protagonist (see figure 2).

The calibanism evident in the text painting of Yupanqui's "Basta ya!" is built on a series of deeper musical transformations, the most fundamental of which is his embrace of solo performance. Played by a dance band comprising two vocalists, guitar, piano, double bass, and percussion, Los Guaracheros' "Al vaivén de mi carreta" evokes stage and audience, suggesting interaction with a crowd through virtuosic vocal lines and instrumental solos and dancing and dancers through driving rhythms and choreographic form. In contrast, the intimacy of Yupanqui's vocal and guitar delivery (a feature exaggerated in the 1971 recording by close microphone work) is notably non-performative. Rather than a staged dance tune about a sugarcane worker, Yupanqui's "Basta ya!" seems to embody the alienated worker himself, facilitating the conflation of his persona with the lyrics and music of his song.

\footnotetext{
${ }^{18}$ The switch to the major mode is anticipated by repeated enunciations of an ascending A major arpeggio in the high register of the guitar. Interpretable as a fanfare, or perhaps a rooster's crow, this gesture would seem to usher in the "new dawn" outlined lyrically in the second half of the song.
} 

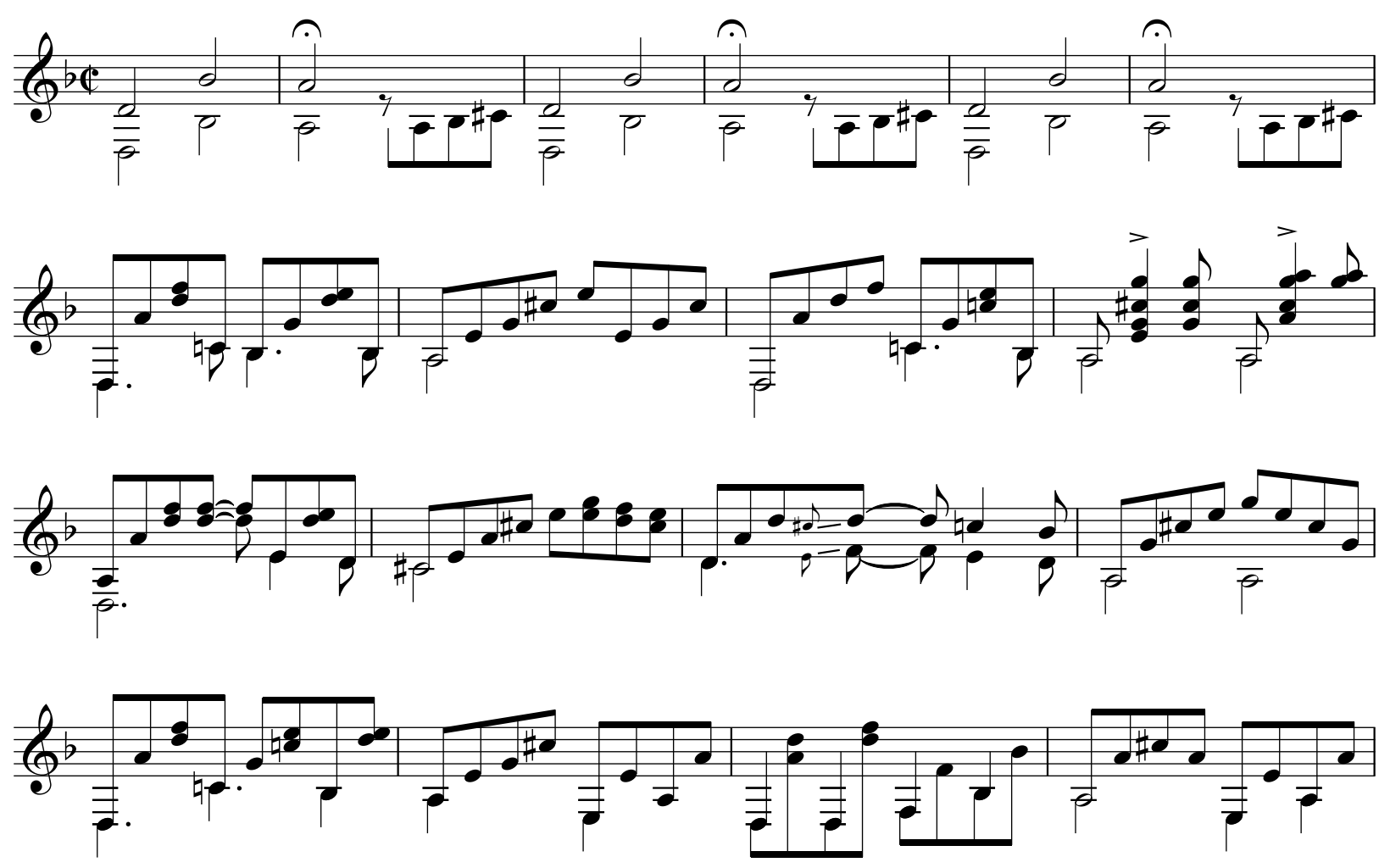

Figure 2: Yupanqui's 1971 guitar introduction to "Basta ya!"

(transcribed by the author from "Basta ya!," Le Chant Du Monde, 1971).

The semantic implications of Atahualpa Yupanqui's solo sound in "Basta ya!" are reinforced and expanded by his calibanistic treatment of the Cuban son. Indeed, although referencing the dance genre identity of "Al vaivén de mi carreta," "Basta ya!" is itself decidedly resistant to choreography. This is especially true in the 1971 version of Yupanqui's song. While Los Guaracheros maintain the same duplemeter rhythmic cell throughout their performance, Yupanqui's guitar accompaniment varies considerably from section to section, shifting rhythmic emphases from measure to measure (see figure 3). A pronounced metric instability adds to the defamiliarization of these rhythms. Rather than following a strict meter, Yupanqui tends to fit rhythmic gestures to the pulse of the spoken word, allocating each line a certain phrase or chord change. ${ }^{19}$ The resultant rhythmic organicism preserves the idea of the son as representative of Latin American subjectivity while discarding its ludic potential. Reinforcing his lyrical calibanism of "Al vaivén de mi carreta," Yupanqui transforms music from a form of diversion to a vehicle for protest, communicating rather than entertaining.

Atahualpa Yupanqui's defamiliarization of the son rhythm in "Basta ya!" is recapitulated in his calibanization of the formal structure of "Al vaivén de mi carreta," a characteristic that further reinforces the song's disassociation with dance. Divided into two similar halves, each introduced by instrumental interludes, Los Guaracheros' son conforms to the relatively-symmetrical confines of a repeating form. Yupanqui's "Basta ya!," for its part, transforms this paradigm into a sprawling, irregular structure. In the first half of the tune, verses borrowed from Nico Saquito's poem are accompanied by melodies and

\footnotetext{
${ }^{19}$ For the sake of legibility, I have chosen to notate the rhythmic cells of "Basta ya!" in cut time, but a more precise representation would have them routinely crossing bar lines, especially during the vocal sections of Yupanqui's song.
} 
harmonies that approximate those of "Al vaivén de mi carreta" (A and B). In the second, two new majormode melodies accompany Yupanqui's original verses and his refrain (C and D). Fractured and unstable, Yupanqui's song would seem meant to be listened to, not danced; understood rather than intuited; ruminated over rather than consumed (see figure 4).
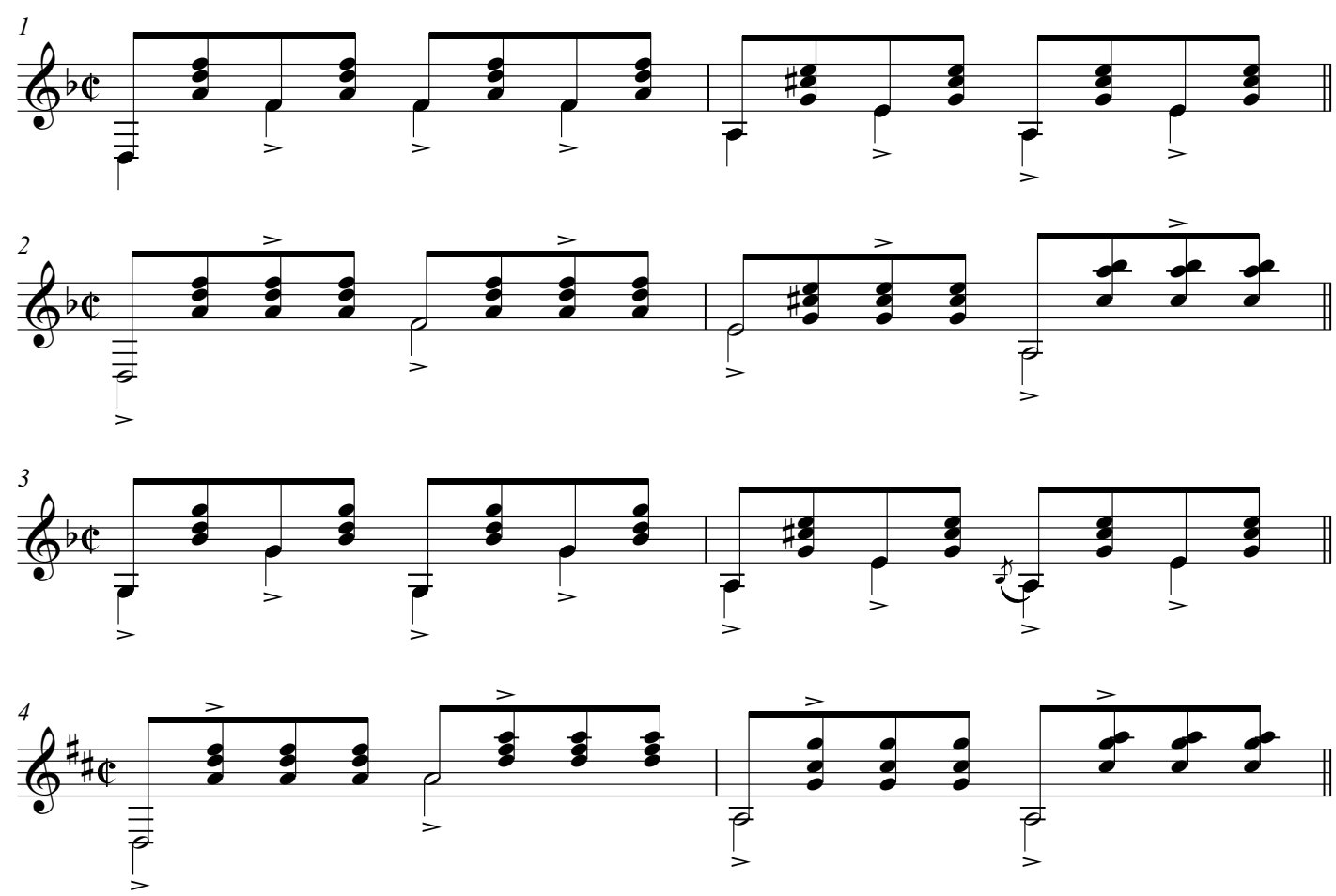

Figure 3: Variations of the son rhythm used by Yupanqui in "Basta ya!"

(transcribed by the author from "Basta ya!," Le Chant Du Monde, 1971).

"Al vaivén de mi carreta" (1950)

\begin{tabular}{|l|l|l|l|l|l|l|l|l|}
\hline I & \multicolumn{10}{l|}{ II } \\
\hline inst. & $\begin{array}{l}\text { verse 1 } \\
\text { (vocal 1) }\end{array}$ & $\begin{array}{l}\text { verse 2 } \\
\text { (vocal 2) }\end{array}$ & $\begin{array}{l}\text { chorus } \\
\text { (duo) }\end{array}$ & inst. & $\begin{array}{l}\text { verse 3 } \\
\text { (vocal 1) }\end{array}$ & $\begin{array}{l}\text { verse 4 } \\
\text { (vocal 2) }\end{array}$ & $\begin{array}{l}\text { bridge } \\
\text { (duo) }\end{array}$ & $\begin{array}{l}\text { chorus } \\
\text { (duo) }\end{array}$ \\
\hline & A & A & B & & A & A & C & B \\
\hline 6 & 2 (eh!) +12 (v.) & $2+12$ & 8 & 8 & $2+12$ & $2+12$ & 12 & 8 \\
\hline
\end{tabular}

“Basta ya!” (1971)

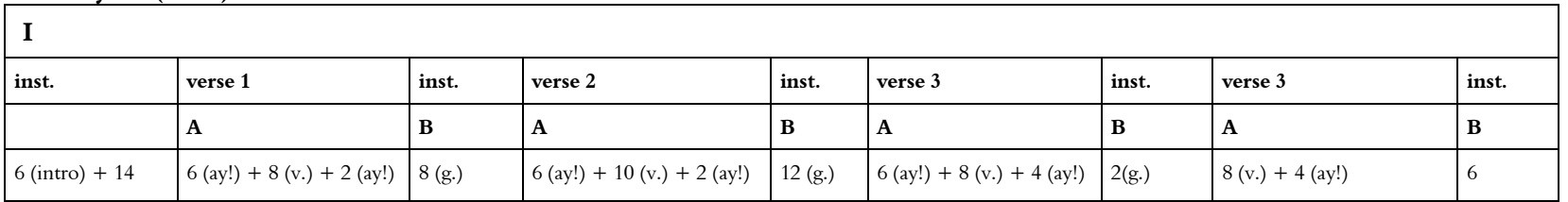

\begin{tabular}{|l|l|l|l|l|l|l|l|l|l|l|l|}
\hline II & chorse \\
\hline inst. & chorus & verse $\mathbf{4}$ & chorus & vers & chorus & verse 6 & chorus & verse 7 & chorus & coda \\
\hline & C & D & C & D & C & D & C & D & C & C' \\
\hline 6 & 12 & 12 & 8 & 12 & 8 & 12 & 8 & 12 & 8 & 4 \\
\hline
\end{tabular}

Figure 4: The formal structures of "Al vaivén de mi carreta" and "Basta ya!" (transcribed by the author from "Basta ya!," Le Chant Du Monde, 1971 and Adiós compay gato - Nico Saquito y los Guaracheros de Oriente, 2015). 
Atahualpa Yupanqui's rejection of vocal and instrumental "professionalism" is a final aspect of "Basta ya!" that can be heard to exemplify the song's aesthetic calibanism. This rejection is particularly evident in Yupanqui's 1971 vocal part (although it is also evident in his 1950 recording). Indeed, in dramatic contrast to the dueling tenors of Los Guaracheros de Oriente, who do their best to approximate operatic voices, Yupanqui's rough, untrained vocals border on recitation, while the virtuosic "grito" yells that open each verse of "Al vaivén de mi carreta" are transformed into harsh moans and the catchy harmonized melody of the chorus is replaced with a shouted refrain ("Basta ya!"). "I'm not a singer, I don't know how to sing, I only converse in D minor," Yupanqui is reputed to have said when asked about his singing style. ${ }^{20}$ Eschewing musical training, the singer-songwriter swallowed the profession of singer whole, embodying the voice of the alienated sugarcane worker described in the lyrics of his song.

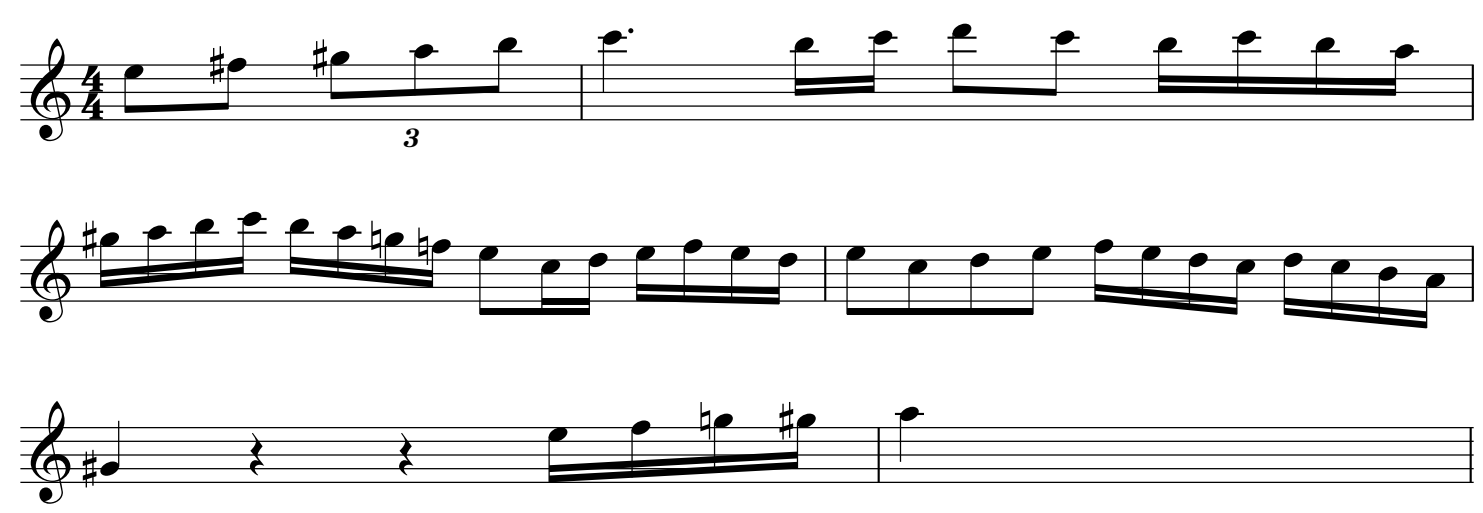

Figure 5: The guitar solo in "Al vaivén de mi carreta" (transcribed by the author from Adiós compay gato Nico Saquito y los Guaracheros de Oriente, 2015).

Atahualpa Yupanqui's guitar playing in "Basta ya!" also spurns the "professionalism" of Los Guaracheros. Take, for example, the introductory bars of each song. In "Al vaivén de mi carreta," a piano and double bass groove lays the foundations for a spectacular guitar solo which, covering the better part of two octaves, blazes up and down the harmonic minor scale with Django Reinhardt-like virtuosic precision (see figure 5). In contrast, Yupanqui's 1971 prelude opens with a repeated, almost ametrical, b6 $\rightarrow 5$ gesture in the bass register, followed by a gritty rendition of a son riddled with "mistakes" and metrical inconsistencies. "No, I didn't transform it, I forgot it," claimed the singer-songwriter, when asked about his formal instruction on the violin and guitar. "I forgot it because when I was seventeen, Almirón (Yupanqui's guitar teacher) went on tour and I never saw him again . . . so I kept playing the things that I really enjoyed. I was interested in the guitar playing I heard among my countrymen, and when I say countrymen, I mean peasants, rough people, people with horses or without horses, but rough ... and the countrymen beat out the academy..." ${ }^{21}$ Rejecting the "professional," Yupanqui can be heard to forge a guitar style that, representative of the marginalized and the oppressed, embodies its voice.

\footnotetext{
20 "Yo no soy cantor, no sé cantar, solo converso en re menor." Cited in Norberto Galasso, Atahualpa Yupanqui: El canto de la patria profunda, 4th ed. (Buenos Aires: Ediciones del Pensamiento Nacional, 2013), 132.

21 "No la fui transformando, la fui olvidando. La fui olvidando porque cuando ya tenía diecisiete años, Almirón se fue de gira y nunca más lo vi ... entonces yo seguí tocando esta cosa que me gustaba tanto. Me interesaba tanto la guitarra que oía siempre a los paisanos y cuando hablo de los paisanos hablo de gente de campo, gente ruda, gente de caballo o sin caballo, pero ruda ... y los paisanos ganaron a la academia ..." Cited in Daniel Viglietti "La canción popular" La del taller: Revista de los talleres de latinoamericanos de música popular, no.7 (1986): 7-11.
} 


\section{The politicization and erasure of "Basta ya!"}

As I have outlined above, Atahualpa Yupanqui's "Basta ya!" is a productive point of departure for exploring the aesthetics of this singer-songwriter's protest songs. But it also provides a representative case study for the Cold War-era contexts in which his lyrical and musical texts were adopted by the "internationalist singing left" and the (often dramatic) ways in which their political meanings were erased from the Argentine public sphere. In the following, I detail the emergence of "Basta ya!" from Yupanqui's Communist Party-sponsored tour of the Soviet Bloc and the subsequent reinterpretation and diffusion of the song by Nueva Canción-affiliated artists and intellectuals. I then briefly outline the role of state and commercial actors in the erasure of the song from Argentine memory.

At the most basic level, "Basta ya!" is an artifact of the intersections between Atahualpa Yupanqui's national and transnational experiences of the Cold War (1945-1989). These intersections are tremendously complex. In Argentina, where Yupanqui spent most of his life until 1968, the singer-songwriter was implicated in a dramatic radicalization of local politics, one in which a long tradition of progressive activism, increasingly stylized in the model of the Cuban Revolution, was brutally counteracted by a succession of autocratic military governments. Yupanqui's local political experience, in its turn, was both directly and indirectly connected to trends in the larger Latin American community, where the singersongwriter toured extensively, and in Europe, where he first achieved international attention during 194951 and where he lived from 1968 until his death in 1992.

Atahualpa Yupanqui's original version of "Basta ya!," first recorded in Paris in 1950, was a direct outgrowth of his affiliation with the Argentine Communist Party (CP), an organization that he joined officially in 1946, but with which he had flirted for several years previously. As with many activists from nation-states on the "periphery" of the Cold War, Yupanqui's initial association with the CP was not necessarily motivated by an attachment to ideological doctrine. A political activist from the early 1930s onwards, Yupanqui seems to have understood the CP as the best platform for resisting the rise of Juan Perón, a figure who he and others perceived as a threat to Argentine democracy. But if Yupanqui's motives for initial involvement in the $\mathrm{CP}$ were based on political pragmatism, he quickly became a mouthpiece for the Party line. Partly as a result of the demands of the CP itself, partly as an outgrowth of the Peronist crackdown on political dissent, the singer-songwriter was increasingly reliant on CP institutions for publication and performance. This attachment culminated in 1949 when, barred from Argentine stages, recording studios, and radios by the Perón administration, he accepted an invitation to represent the Argentine Communist Party on a tour of the Soviet Bloc.

Yupanqui's 1949-50 trip to the Soviet Bloc, which included visits to Hungary, Romania, and Bulgaria and concluded with a series of recording sessions with French labels Le Chant Du Monde and La Boîte à Musique, induced a dramatic change in his music. Lyrically speaking, songs like "Basta ya!," which was written specifically for the tour, ${ }^{22}$ broke from the musical models that had inspired most of his previous repertoire, evincing a notable shift towards the embodiment of "workers" and a pronounced advocacy of revolutionary action. Musically, a turn to "international" music styles reinforced lyrical messages of global proletarian uprising. Indeed, as I will explore in some detail in the second part of this

\footnotetext{
${ }^{22}$ As Yupanqui wrote to his wife, Nenette on July 5, 1950: "Esa canción que no conoces se llama "Basta ya". Es canto antiimperialista, que arreglé de una canción del Caribe, y ha resultado un éxito entre los sectores anti facistas de Europa. Todo el mundo me la pide, y muchos cantores de Bucarest, Sofía, Budapest, y aún de París la han copiado para cantarla." Víctor Pintos, ed. Cartas a Nenette (Buenos Aires: Editorial Sudamericana, 2001), 67.
} 
article, Yupanqui wrote and performed music almost exclusively in "Argentine" genres before and after his "communist period." In contrast, several of his new "communist" songs were based on cosmopolitan sounds. ${ }^{23}$

Although similar in lyrical and musical content, and distributed on the same French record label (Le Chant Du Monde), the version of "Basta ya!" that Atahualpa Yupanqui recorded two decades later, in 1971, was freighted with a host of new meanings. Abstractly speaking, this semantic transformation can be attributed to the emergence of the New Left, which helped to associate Yupanqui's music with the unique circumstances of Latin America rather than the more abstract revolutionary role of the proletariat. More concretely, the revival can be understood as a reaction to, and assimilation of, the embrace of his music by the protagonists of the Nueva Canción. Learning of songs like "Basta ya!" through a decentralized network of cosmopolitan activists, the Chilean ensemble Quilapayún used the song as the title track for their 1969 album Basta ya, interpreting it as a call for the liberation of Latin America through Cuban-inspired militancy. Other Nueva Canción musicians followed suit.

Documents related to the Primer Encuentro de la Canción Protesta, a meeting of activist singers held by the Cuban Casa de las Americas in 1967, give a sense of the radicalized perspectives that attracted Nueva Canción musicians like Quilapayún to Yupanqui's work. Organized in the hope of fomenting music dedicated to the "fight for the liberation of the people from North American imperialism and colonialism," ${ }^{24}$ the meeting incorporated musicians from around the world, including the Americas, Europe, and Vietnam. Latin American attendees held particularly militant views on the role of music in the liberation of the Third World. Advocating that the term "protest song" be replaced with "fighting songs" and "rebel songs," for example, the 28-year-old singer-songwriter Daniel Viglietti tied indigenous American identity to armed resistance: "Give your hand to the Indian" he wrote in a version of "Canción para mi América" reworked especially for the Encuentro: "a copper hand will show you/ the blood you will need to give ... it is the time of copper/ mestizos, shouts and guns/ if they don't open the doors/ the people will open them . . . Let's defeat the traitors and the Yankees that imperialism brought."25

Although there is no direct reference to Atahualpa Yupanqui in the minutes of the Primer Encuentro de la Canción Protesta, Méri Franco-Lao's contemporaneous book Basta! Canciones de testimonio y rebeldía de América Latina, gives a good sense of the Nueva Canción's emergent radicalization of Yupanqui's songs. ${ }^{26}$ Published in France in the months immediately preceding the conference, and likely available at the Encuentro itself, Basta! anticipates the work of Ariel Dorfman's and Eduardo Galeano's Marxist interpretations of Latin American culture, ${ }^{27}$ using song lyrics from across the Americas as points of departure for the exploration of the "stages" of regional history. Atahualpa Yupanqui's music plays a central role in Franco-Lao’s book. Many are taken from Yupanqui’s communist-period recordings of 1950, all are

\footnotetext{
23 "Duerme negrito" (recorded on La Boîte à Musique) and "Shoro" (recorded on Le Chant du Monde) are the two other examples of this trend.

24 “Los creadores, intérpretes y estudiosos reunidos en este primer Encuentro de la Canción Protesta realizado en Cuba, primer territorio libre de América, saludamos la iniciativa de la Casa de las Américas que nos ha permitido conocernos, intercambiar experiencias y comprender el alcance de nuestra labor así como el importante papel que cumplimos en la lucha de liberación de los pueblos contra el Imperialismo Norteamericano y el Colonialismo." Cited from the Resolución final del Encuentro de la Canción de Protesta of August 4, 1967.

25 "Dale tu mano al indio/ dale, que te hará bien ... Es el tiempo del cobre/ mestizo, grito y fusil/ si no se abren las puertas/ el pueblo las ha de abrir . . Resueltos, torturados/ oprimidos, llenos de odio/ derrotamos ya a los traidores y a los yanquis que el imperialismo llegó.” Published in Canción Protesta, no.1 (1968): 49.

${ }^{26}$ Méri Franco-Lao, Basta! Canciones de testimonio y rebeldía de América Latina (México D.F.: Biblioteca ERA, 1970).

Thanks to Manuel Vilches Parodí for introducing me to this text.

27 Para leer al Pato Donald (1972) and Las venas abiertas de América Latina (1971), respectively.
} 
seen to represent the voices of the marginalized and the oppressed. "Basta ya!," which appears immediately before a chapter titled "Y en eso llegó Fidel . ..," 28 is both localized and radicalized, transformed into a celebratory cry for Latin American liberation in the Cuban image.

The revival of "Basta ya!" by the "internationalist singing left" was accompanied by equally powerful efforts at suppressing the song in Argentina. Banned by the Argentine state and spurned by national record labels, neither Yupanqui's 1950 nor 1971 versions of "Basta ya!" were commercially performed, recorded, or distributed in the country; both were probably known only through hearsay or bootlegged cassettes until the advent of digital media. Even today, the song is notably absent from the Argentine public sphere, a reality reflected in a variety of contexts, from the Yupanqui exhibit at the Centro Cultural Kirchner national museum, which conspicuously omits Yupanqui's relationship to the Communist Party and the Nueva Canción, to Soledad Pastorutti's popular "Don Ata" (1996), a rollicking, cumbia-like tribute song that reduces the meaning of Yupanqui's work to a string of nostalgic regionalisms.

The erasure of "Basta ya!" from the Argentine public sphere is most easily attributable to Cold Warera state censorship. Written during his 1949-50 tour of the Soviet Bloc, "Basta ya!" was first performed and recorded in Europe, and the "anti-communist" cultural policies of Cold War-era Argentine governments effectively effaced it from his national repertoire. Such policies appear to have been relatively unbroken during the twentieth century, at least until the Argentine return to democracy in 1983. Banned from national stages and recording studios from 1948 to $1953,{ }^{29}$ and required to publicly renounce his Communist Party affiliation in order to re-enter public life, Yupanqui continued to be subjected to intense political scrutiny throughout the 1950s and 1960s. The policies of the military junta of 1976 to 1983 were particularly extreme, prohibiting Yupanqui's music in both live and recorded form and terrorizing his politically progressive audiences. ${ }^{30}$

And yet, if the regulatory power of the Argentine state provided the impetus for the suppression of "Basta ya!," the central actors in its Cold War-era erasure were the multinational record companies responsible for recording and distributing Atahualpa Yupanqui's music in Argentina. In its most overt form, this discographic effacement took the guise of exclusion: Yupanqui's Argentine labels, Odeon/EMI and Victor/RCA, did not record or distribute "Basta ya!," thus rendering it inaccessible to all but the most cosmopolitan of Argentines. Equally importantly, the Yupanqui songs that Odeon/EMI and Victor/RCA did choose to record and distribute tended to reinforce a traditionalist image of the singer-songwriter as a "singing gaucho" cowboy. Re-releasing Nativist- style songs recorded before Yupanqui's communist affiliation and supplementing them with new compositions in a similar style, these albums excised Yupanqui's protest music, implying an undisrupted, and decidedly apolitical, creative continuity. ${ }^{31}$

\footnotetext{
28 "And that's when Fidel arrived ..."

${ }^{29}$ Víctor Pintos' depiction of Atahualpa Yupanqui's return to early 1950s Argentina reflects the severity of the Peronist blacklist: "El regreso de Europa no fue feliz. A fin del invierno de 1950, Yupanqui sufrió una serie de detenciones bajo diversos cargos, ninguno de ellos suficientemente claro. Por ejemplo, una vez lo acusaron de haber orinado en la calle y terminó preso en un calabozo de seccional policial. Y más aún: llegó a estar preso varios meses . . e en el cárcel de Devoto, sin proceso ni condena.” Víctor Pintos, ed. Cartas a Nenette (Buenos Aires: Editorial Sudamericana, 2001$), 69$.

${ }^{30}$ An estimated 30,000 Argentine "political activists" were "disappeared" during this period, which is often referred to as the "Dirty War."

${ }^{31}$ I am indebted to Patrick Clonrozier's digital archive for these and other observations regarding Yupanqui's discography. See www.atacris.com.
} 
Judging from both his Argentine public appearances and the public statements he made during the 1960s and 1970s, Atahualpa Yupanqui appears to have been disconcertingly complicit with the domestication of his Argentine image. Featured increasingly in Argentina cinema as a Mariachi-like singing gaucho cowboy, Yupanqui publicly embraced a persona that conflated him and his music with an unchanging Argentine "tradition." More unsettling still, Spanish-language interviews given in the early 1970s (precisely at the moment in which he was re-recording "Basta ya!" in France), suggest an active rejection of musical activism. "I don't believe in professional protest singers," declared Yupanqui in 1971 in one of his many public denunciations of the Nueva Canción. "If someone wants to scream his pamphlets to music in public, let him do it. But he isn't an artist." ${ }^{32}$ In other similarly cantankerous outbursts, the singer-songwriter would characterize Nueva Canción stars like Jorge Cafrune and Quilapayún as "opportunists" and "rabble rousers."33

From a neoliberal perspective, Atahualpa Yupanqui's simultaneous embrace of traditionalism in Argentina and radicalism in France reflects the market-driven opportunism of a performing musician intent on building an international career. ${ }^{34}$ Placed within the political context of the Cold War, however, it seems more accurate to characterize it as a political imperative-and perhaps even a political strategy. Indeed, following the Argentine "Liberatory Revolution" of 1966, a military takeover whose initial impacts included the expulsion and forced exile of hundreds of artists and intellectuals, Yupanqui was faced with the familiar choice of banishment or silence. He chose both and neither. Leaving Argentina on a global tour in 1967, the singer-songwriter set up a semi-permanent residence Paris, reviving communist-period protest songs like "Basta ya!" for European audiences. Unlike his previous experiment with political activism in the 1950s, however, the older (and perhaps wiser) Yupanqui did not overtly confront military regimes. Thus, in his frequent visits to Argentina and (Franco-controlled) Spain during the early 1970s, he refrained from overt shows of political resistance — much less public performances of "Basta ya!"-and even acted the part of the conservative. Regardless of its intention, this strategy allowed him to play a central role in Argentine musical life while simultaneously supporting and inspiring the Nueva Canción.

\section{Beyond "Basta ya!": Atahualpa Yupanqui's other protest songs}

The aesthetic calibanism and Cold War-era reception history outlined in my analysis of "Basta ya!" provide a productive point of departure for explaining the political power of the two dozen or so additional Atahualpa Yupanqui compositions commonly understood as protest songs. From a lyrical and biographical perspective, much of this material would seem to have little relationship to "Basta ya!" Textually, few of the songs in question have equivalently topical lyrical content. Contextually, only a handful were written during Yupanqui's "communist period." And yet, as a comparison with "Basta ya!" will show, the Yupanqui songs commonly identified as "protest songs" do have important commonalities. Not only do most share a distinctly calibanistic aesthetic (albeit in relationship to a less internationally-recognized

\footnotetext{
32 "No creo en los profesionales de la canción de protesta. El que quiera gritar sus panfletos públicamente y con música, que lo haga. Pero ése no es un artista.” This quote is first cited by Félix Luna, who attributes it to a March 1971 interview published in the Buenos Aires magazine Extra. See Félix Luna, Atahualpa Yupanqui (Madrid: Ediciones Júcar, 1973 ), 53.

${ }^{33}$ Carlos Molinero and Pablo Vila, "Atahualpa Yupanqui: The Latin American Precursor of the Militant Song Movement," in The Militant Song Movement in Latin America, edited by Pablo Vila (New York: Lexington Books, 2015), 189; Guillermo Pellegrino, Las cuerdas vivas de América. (Buenos Aires: Editorial Sudamericana, 2002), 276.

${ }^{34}$ For a series of excellent analyses of Argentine popular musicians in this vein, see Matthew B. Karush, Musicians in

Transit: Argentina and the Globalization of Popular Music (Durham, NC: Duke University Press, 2017), https://doi.org/10.1215/9780822373773.
} 
musical referents than the Cuban son), the majority evidence a common trajectory of international politicization in the mouths of the "internationalist singing left" and state- and industry-induced erasure in the Argentine public sphere.

\section{Aesthetic calibanism}

Hearing the aesthetic calibanism of the majority of Atahualpa Yupanqui's protest songs requires familiarity with the commercial representations of Argentine folk music, or "Folklore" (folk-lor-ay), that most of them transform. Like "Al vaivén de mi carreta," the preponderance of these referents were commercialized popular dances. Standardized and nationalized by the "Native" variety shows that toured Argentina during the late nineteenth and early twentieth centuries, ${ }^{35}$ instrumental dance genres like the chacarera, the gato, and the zamba comprised elaborate stage routines intended to communicate the flavor of Argentina's rural cultures for urban audiences, many of which had only recently arrived in the country. ${ }^{36}$ In tandem with the gradual disappearance of these variety shows during the 1930s and 1940s, a generation of recording artists, including the Gardel-Razzano duo, Buenaventura Luna's Tropilla de Huachi Pampa, ${ }^{37}$ and the Antonio Tormo ensemble, began to capture their choreography-driven dramaturgy in popular song. An explosion of commercial groups often referred to as the "Folklore Boom" brought this trend to its apogee in the 1950s and 1960s.

Like many of his contemporaries in the field of Argentine popular music, Atahualpa Yupanqui rode on the coattails of the Native variety show, referencing Folklore genres to legitimize an unapologetically populist persona. But, as Ricardo Kaliman has argued with respect to Yupanquils lyrics, the singersongwriter's approach to Folklore could also be markedly calibanistic. Indeed, whereas Native variety shows transmitted a socially conservative portrayal of rural life, legitimizing social inequality through the depiction of dancing peons and idyllic landscapes, Yupanqui's poetry could often be better characterized as social critique. ${ }^{38}$ While songs like "El arriero va," "Canción de cañaveral," and "Juan" portray suffering workers alienated from the means of agricultural and mineral production, others, like "Preguntitas sobre Dios," "El poeta," and "Trabajo, quiero trabajo," express aversion to social injustice, and often call for transformative-if not revolutionary-action.

Also like "Basta ya!," the lyrical transformation evident in many of Atahualpa Yupanqui's Folkloreinspired protest songs is accompanied by a pronounced musical calibanism; a reworking of the performative variety show into a "non-professional" embodiment of the marginalized and the oppressed. On the one hand, Yupanquils eschewal of the highly-polished professionalism of the Argentine Folklore ensemble, which tended to feature two- or three-part vocal arrangements, virtuosic guitar parts, and elaborate "bombo" drum solos, aligned his music with that of contemporary North American musical activists like Woody Guthrie and Pete Seeger and set it apart from the overtly commercial productions of

\footnotetext{
${ }^{35}$ For more on the history of the Native variety show, see Julius Reder Carlson, “The 'Chacarera Imaginary': 'Santiagueñan' Folk Music and Folk Musicians in Argentina." (UCLA, 2011).

36 Sung genres like the "pampean" milonga and estilo were also central to the Argentine "Nativist" stage and appear with some frequency in Atahualpa Yupanqui's work.

${ }^{37}$ The political trajectory of Buenaventura Luna, whose support of the first Perón administration seems to have been a key factor in his commercial success during the late 1940s and early 1950s, is outlined in Ezequiel Adamovsky, "Criollismo, política y etnicidad en las y ideas y folklore de Eusebio Dojorti (Buenaventura Luna)," Studies in Latin American Popular Culture, vol. 24 (2016): 242-271, https://doi.org/10.7560/SLAPC3412.

${ }^{38}$ Ricardo Kaliman supports his argument with lyrical analyses of "Zambita de los pobres" and "La pobrecita." Ricardo Kaliman, Alhajita es tu canto (Córdoba, Argentina: Editorial Comunicarte, 2004).
} 
the 1930s and 1940s, not to mention those of the later Folklore Boom. The solo aspect of his work is equally_if not more-significant. Indeed, with several notable exceptions Yupanqui was among the few Argentine Folklore singer-songwriters to perform and record as a soloist before the Nueva Canción era. ${ }^{39}$ And given the prominence of Yupanqui-influenced solo singer-songwriters like Jorge Cafrune, Víctor Jara, and Daniel Viglietti to the Nueva Canción movement, it is worth considering this aspect of Yupanqui's calibanism as one of his signature contributions to the protest song tradition in South America.

Beyond performance style, the most salient aspect of musical calibanism in the majority of Atahualpa Yupanqui's protest songs—and perhaps the way in which they most resemble "Basta ya!"-is their rejection of formal and rhythmic dance genre conventions. Fusing "Argentine" dance genres with timbres evocative of "Andean" music, the musical style of many of these songs can be heard to reinforce their lyrical connection with "indigenous" alterity. ${ }^{40}$ A rejection of formal and rhythmic conventions akin to "Basta ya!" supplements this stylistic transformation. Formally speaking, Yupanqui's Folklore-inspired protest songs tend to approximate Argentine folk dances without actually adhering to their formal designs, resulting in strophic or binary "canciones" with often-noticeably irregular sectional lengths. Rhythmically, the metric instability and constant mutability of Yupanqui's guitar parts, combined with his tendency to mix and match syncopations from diverse genres, makes his "dances" choreographically untenable (See figures 6-9 for more detailed analysis). ${ }^{41}$

"El arriero va" (1944)

\begin{tabular}{|l|l|l|l|l|l|l|l|l|}
\hline inst. & verse 1 & verse 2 & chorus & inst. & verse 3 & verse 4 & chorus & coda \\
\hline & A & A & B & & A & A & B & A' \\
\hline zamba + malambo & zamba & zamba & chacarera & zamba + malambo & zamba & zamba & chacarera & zamba \\
\hline 8 (mel.) +4 (str.) & 15 (v.) +4 (g.) & $15+4$ & $16+2$ & $8(\mathrm{~m})+.4(\mathrm{~s})$. & $15+1$ & $15+4$ & $16+5$ & $7+2$ \\
\hline
\end{tabular}

Figure 6: "El arriero va" bears many structural similarities to the AAB zamba form, but does not conform to its standard 12-bar sectional lengths. The guitar accompaniment vacillates between zamba, chacarera, and malambo rhythms (transcribed by the author from Yupanqui's 1944 Odeon recording).

\section{"Preguntitas sobre Dios" (1950)}

\begin{tabular}{|c|c|c|c|c|c|c|c|c|}
\hline \multicolumn{3}{|l|}{ verse 1} & \multicolumn{6}{|l|}{ verse 2} \\
\hline inst. & A & B & \multicolumn{2}{|l|}{ inst. } & \multicolumn{2}{|l|}{ A } & \multicolumn{2}{|c|}{ B } \\
\hline 8 (melody) +2 (strum) & 12 & 12 & \multicolumn{2}{|l|}{3 (strum) } & \multicolumn{2}{|l|}{8} & \multicolumn{2}{|c|}{12} \\
\hline \multicolumn{3}{|l|}{ verse 3} & \multicolumn{6}{|l|}{ verse 4} \\
\hline inst. & A & B & inst. & A & & B & & B' (coda) \\
\hline 3 & 8 & 12 & 2 & 8 & & 12 & & 12 \\
\hline
\end{tabular}

Figure 7: "Preguntitas sobre Dios" is a strophic song bearing little formal resemblance to an Argentine folk dance. The guitar accompaniment implies a zamba rhythm, albeit with a pronounced "Andean" flare (transcribed by the author from Yupanqui's 1950 Le Chant Du Monde recording).

\footnotetext{
${ }^{39}$ Among these exceptions is Gabino Ezeiza, one of Argentina's first great popular recording artists, although he might be better understood as a precursor to, rather than a participant in, Argentine Folklore.

${ }^{40}$ For a transnational history of "Andean" music and its political associations, see: Fernando Rios, "La Flûte Indienne: The Early History of Andean Folkloric-Popular Music in France and Its Impact on Nueva Canción” Vol. 29, No. 2 (Fall - Winter, 2008): 145-189, https://doi.org/10.1353/lat.0.0022.

${ }^{41}$ It is worth noting that formal and rhythmic calibanism, like its lyrical counterpart, was not a universal aspect of Yupanqui's oeuvre. As original songs like "Zamba del grillo" and "Chacarera de las piedras" attest, Yupanqui was fully capable of writing and performing normative Folklore dances.
} 
“Trabajo, quiero trabajo” (1957)

\begin{tabular}{|l|l|l|l|l|l|l|l|l|l|l|l|l|l|l|l|}
\hline inst. & verse 1 & verse 2 & chorus & chorus & inst. & verse 1 & verse 2 & chorus & chorus & inst. & verse 1 & verse 2 & chorus & chorus & coda \\
\hline & A & A & B & B & & A & A & B & B & & A & A & B & B & C+B' \\
\hline $8(\mathrm{~m})+5(\mathrm{~s})$ & 8 & 8 & 8 & 8 & $8+7$ & 8 & 8 & 8 & 8 & $8+5$ & 8 & 8 & 8 & 8 & $8+4$ \\
\hline
\end{tabular}

“Trabajo, quiero trabajo" (1969)
\begin{tabular}{|l|l|l|l|l|l|l|l|}
\hline inst. & verse 1 & verse 1 & chorus & inst. & verse 2 & verse 2 & chorus \\
\hline & A & A & B & & A & A & B \\
\hline 8 (melody) $+3($ strum) & 8 & 8 & 8 & $8+5$ & 8 & 8 & 8 \\
\hline
\end{tabular}

\begin{tabular}{|l|l|l|l|l|l|l|l|}
\hline inst. & verse 3 & verse 3 & chorus & chorus & verse 4 & verse 4 & chorus \\
\hline & A & A & B & B & C & C & B' \\
\hline $8+7$ & 8 & 8 & 8 & 8 & 8 & 8 & 4 (sung) +4 (guitar) \\
\hline
\end{tabular}

Figure 8: Comparison of Yupanqui's 1957 and 1969 versions of "Trabajo, quiero trabajo" demonstrates the song's formal fluidity. The guitar accompaniment is akin to a zamba rhythm in the 1957 version and approximates a chacarera rhythm in the 1969 version (transcribed by the author from Guitarra dímelo tú..., Antar, 1957 and Soy libre! Soy bueno!, Le Chant Du Monde, 1968).

"Juan" (1969)

\begin{tabular}{|l|l|l|l|l|l|l|l|l|l|l|}
\hline inst. & verse1 & verse 1 & verse 2 & inst. & verse 3 & verse 3 + 5 & inst. & verse 6 + 5 & verse 1 & verse 5 \\
\hline & A & A & B +B' & & C & C+B' & & B +B' $^{\prime}$ & A & B'+B' $^{\prime}$ \\
\hline $8(\mathrm{mel})+.2(\mathrm{str})$. & $8(\mathrm{v})+2(\mathrm{~g})$ & $8+2$ & $4(\mathrm{v})+1(\mathrm{~g})+4(\mathrm{v})+3(\mathrm{~g})+4(\mathrm{v})$ & $8+2$ & $8+2$ & $8(\mathrm{v})+1(\mathrm{~g})+4(\mathrm{v})$ & 4 & $8(\mathrm{v})+2(\mathrm{~g})+4(\mathrm{v})+2(\mathrm{~g})$ & $8+2$ & $4+4$ \\
\hline
\end{tabular}

Figure 9: "Juan" expands upon the AAB zamba form to build a complex, organic, structure. The guitar accompaniment is akin to a zamba rhythm (transcribed by the author from Preguntitas sobre Dios, Le Chant Du Monde, 1969).

\section{Politicization and erasure}

In addition to highlighting the lyrical and musical calibanism shared by Atahualpa Yupanqui's protest songs, the case of "Basta ya!" exemplifies the role of Cold War-era political contexts in their politicization and erasure. On the one hand, all of Yupanqui's protest songs are songs of the "internationalist singing left," having been associated with the Communist Party in the late 1940s and early 1950s, revived by the Nueva Canción in the 1960s and 1970s, or some combination of the two. Equally significantly, the politicization of these songs was almost always accompanied by some degree of suppression or erasure in Argentina. Like "Basta ya!," a significant portion of Yupanqui's protest repertoire was only recorded by him in international studios. Much of it was difficult for Argentines to access between 1948 and 1983.

The first way in which the reception history of "Basta ya!" sheds light upon the politicization of Atahualpa Yupanqui's protest repertoire is by highlighting the intentionality of its contestatory meaning. This is certainly the case for songs like "Duerme negrito" and "Preguntitas sobre Dios," which were written contemporaneously with "Basta ya!" for performance during Yupanqui's tour of the Soviet Bloc, and which often received overtly political epithets on recording jackets and concert programs. ${ }^{42}$ But, in

42 "Duerme negrito," for example, is referred to as "song of a proletarian mother" ("canción de la madre proletaria") on an unreleased recordings for Melodías y Danzas Argentinas (1955). 
contrast to the claims of some historiographers, many of whom have taken Yupanqui's verbal rejections of the Nueva Canción at face value, the reception history of "Basta ya!" suggests that Yupanqui remained politically radicalized well after his official break from the Communist Party in $1953 .{ }^{43}$ Indeed, not only did Yupanqui himself play a role in the revival of his communist period songs during the 1960s and 1970s, he also wrote new contestatory material later in his career, from tunes like "Guitarra dímelo tú," "El poeta," and "Trabajo, quiero trabajo," which he recorded immediately following the collapse of the first Perón administration (1957), to songs like "Canción para Pablo Neruda," "Los hermanos," and "Juan," which he wrote during the Nueva Canción era.

If the genesis of "Basta ya!" suggests a continuity in Atahualpa Yupanqui's ideological convictions, the revival of the song during the 1960s and 1970s highlights the role of third-party actors in the process of semantic radicalization experienced by much of his protest repertoire. Two central actors in this processthe Communist Party and the Nueva Canción-played roles at different periods over the course of the twentieth century. During Yupanqui's affiliation with the Communist Party, a small corpus of his preexistent songs including "El arriero va," Piedra y camino," and "La pobrecita" seem to have acquired new, highly politicized, connotations through inclusion in CP functions and publications. ${ }^{44}$ The revival of these and other songs by the Nueva Canción in the 1960s and 1970s had a similar effect. Embraced by politically left-leaning performers including Jorge Cafrune, Víctor Jara, Ángel Parra, Quilapayún, Mercedes Sosa, and Daniel Viglietti, compositions like "Canción de cañaveral," "Duerme negrito," "Guitarra dímelo tú," "El poeta," and "Preguntitas sobre Dios" followed a parallel trajectory to "Basta ya!," becoming anthems of South American "revolutionary" politics with the help of a loose affiliation of cosmopolitan cultural actors. ${ }^{45}$ Whether the overtly political LPs that Yupanqui made with Le Chant Du Monde from 1969-1971 are understood as a reaction to, or an impetus for, this revival is open to interpretation. In either case, these four albums include the vast majority of what are now considered Yupanqui's protest songs. ${ }^{46}$

Another significant contribution of "Basta ya!" to the understanding of Atahualpa Yupanqui's protest songs is the clarity with which it demonstrates the Argentine censure that accompanied their adoption by the "internationalist singing left." This suppression is particularly clear for Yupanqui's version of "Preguntitas sobre Dios," which, in a manner similar to "Basta ya!," was not commercially released in Argentina until the 1980s. But it is also evident for more lyrically ambiguous protest songs, many of which were only recorded by Yupanqui outside of the country in the period between his Peronist blacklisting (1948) and the return of Argentine democracy (1983) (see figure 10). ${ }^{47}$ That this pattern of suppression was enforced rather than voluntary is suggested by Yupanqui's repeated attempts to record protest material in Argentine studios, from never-released takes of "Duerme negrito," "El pintor," and "Preguntitas sobre Dios" on Melodías and Danzas Argentinas (1955), to versions of "El arriero va" and "Preguntitas sobre Dios" omitted from his recordings by Odeon/EMI in the 1970s. The density of protest songs released on internationally recorded LPs like Guitarra dímelo tú (Antar, Uruguay, 1957) and Soy libre! Soy bueno! (Le Chant Du Monde, France, 1968), meanwhile, reinforces the "illicit" nature of these songs in Argentina, as

\footnotetext{
${ }^{43}$ Although it is important to note that this political activity was not necessarily connected to the Communist Party.

${ }^{44}$ The Communist Party-affiliated publication Tierra que anda (1948) includes scores for "El arriero va" (1944) and Piedra y camino" (1944). The guitar solo "La pobrecita" (1946) was re-recorded on Le Chant Du Monde in 1950.

45 "Duerme negrito," "Canción de cañaveral," "Canción del pampino," and "Preguntas sobre Dios" were included in FrancoLao's Basta!!

${ }^{46}$ Yupanqui recorded four Le Chant Du Monde LPs during this period including Soy libre! Soy bueno! (1968), Campesino Duerme negrito (1969), Preguntitas sobre Dios (1969), and Basta ya (1971).

${ }^{47}$ As Patrick Clonrozier has suggested, copyright considerations may have also played a role in Yupanqui's recording career. This will need to be explored in future research.
} 
does the content of Las Preguntitas, an EMI LP that appeared in Argentina immediately following the collapse of the military junta.

\begin{tabular}{|c|c|c|}
\hline & Year recorded & Recording location \\
\hline "El arriero va" & $1944 / 1969 \star / 1974 \star / 1978^{\star}$ & Arg./France/Mexico/Arg. \\
\hline "Piedra y camino" & 1944 & Arg. \\
\hline "La pobrecita" & $1946 / 1950 \star / 1971^{\star}$ & Arg./France/France \\
\hline "Basta ya!" & $1950 \star / 1971^{\star}$ & France/France \\
\hline "Preguntitas sobre Dios" & $1950 \star / 1969 \star / 1974 \star / 1974 \star$ & France/France/Arg./Mexico \\
\hline "Guitarra dímelo tú" & $1957 / 1968$ & Uruguay/Spain \\
\hline "El pintor" & $1957 / 1968^{\star}$ & Uruguay/France \\
\hline "El poeta" & 1957/1968^/1968 & Uruguay/France/Spain \\
\hline "Trabajo, quiero trabajo" & 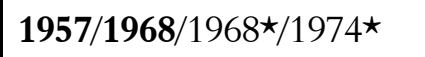 & Uruguay/Spain/France/Mexico \\
\hline "Campesino" & 1968/1969*/1970 & Spain/France/Spain \\
\hline
\end{tabular}

${ }^{\star}$ ) not released in Argentina before 1983

(bold) recorded abroad but released in Argentina

Figure 10: The absence of Argentine-made recordings of many of Yupanqui's protest songs between 1948 and 1983 suggests a degree of intentional or de-facto censorship (data collected by the author from the collection of Patrick Clonrozier).

The versions of Atahualpa Yupanqui songs released by Folklore Boom artists of the 1950s and 1960s were an essential component of the political erasure effected by multinational record companies. In a pattern established early in his musical career, Yupanqui's compositions were often best known to Argentines in the interpretations of other performers, a situation that took on political weight following the Peronist blacklisting of 1948 when, unavailable to the listening public, the calibanistic sound of his performances was replaced by the highly manicured renditions of Folklore Boom ensembles, transforming lyrically ambiguous songs like "El arriero va" and "La pobrecita" into popular dance-hall tunes. Whether interpreted as commercial pragmatism or a kind of covert political activism, Yupanqui himself contributed to the depoliticization of several of his protest songs for Argentine distribution, including "Duerme negrito," which he rebranded as a folk tune "from the border of Venezuela and Colombia" and "Baguala de los mineros," which he re-recorded as a guitar solo under the title "Minero soy." The lyrical polyvalence of songs like "El payador perseguido," suggests that some of this depoliticization was indeed political strategy. Semantically ambiguous enough to be recorded and distributed in Argentina, this albumlength recited poem drew on the nineteenth-century figure of the gaucho Martin Fierro as an autobiographical resource, framing Yupanqui as both an icon of conservative nationalism and an outlaw. 


\section{Beyond Atahualpa Yupanqui: Some general thoughts on the analysis of protest song}

To date, the scholarly discussion of protest song has taken two separate approaches to this genre. While one body of literature has concentrated on textual content, striving to define a protest song "paradigm" through lyrical analysis, the other has explored reception history, documenting the ways in which protest songs are used by diverse individuals and communities. An exploration of Atahualpa Yupanqui's protest songs suggests that these two approaches are complementary, if not inseparable, driving home the mutual contingency of text and context in the genesis of musical meaning. On the one hand, songs like "Basta ya!" were inspired and promoted by the mid-century Communist Party and imbued with new meanings by the Nueva Canción. On the other, it is unlikely that either of these communities would have embraced these songs were it not for their calibanistic lyrical and musical content.

In addition to modeling a fusion of textual and contextual methodologies, an examination of Atahualpa Yupanqui's songs raises themes as of yet relatively unexplored in the protest song literature. With respect to text, it suggests that musical aesthetics are as fundamental as lyrical content in the politicization of protest songs, inflecting, standing-in for, and at times replacing, lyrical meanings. With respect to reception history, meanwhile, it points not only to the role of the musicians and audiences who politicize and radicalize music, but also to the state and commercial institutions who censor and suppress it. For if songs like "Basta ya!" were used as ideological vehicles by an "internationalist singing left," they were also shaped by state-induced blacklists and record label restrictions, factors that at least partially explain their absence from significant sectors of the Argentine public sphere.

Finally, the analysis of songs like "Basta ya!" highlights the importance of a vigorously critical approach to the meanings of protest songs. On a textual level, it is a reminder that musical and lyrical content, and the significance of this content, is kaleidoscopic, changing from listener to listener and time period to time period. On the level of reception history, meanwhile, it reinforces the opacity of source material, both documentary and discursive. On the one hand, the evidence provided by the recording industry and the popular press - in many cases the only "traditional" documentation available-is frequently complicit in the erasure and suppression of protest song. On the other, the public discourse of protest musicians and audiences is often heavily circumscribed. To write about protest song, then, is in many ways to read between the lines. The failure to do so risks reinforcing the very hegemonic narratives that songs like "Basta ya!" were often heard—and likely also intended—-to resist and destabilize.

\section{Bibliography}

Abdala, Eliana E. La poesía de Atahualpa Yupanqui: “. . guitarra dímelo tú. ”Buenos Aires: Corregidor, 2016.

Adamovsky, Ezequiel. "Criollismo, política y etnicidad en las y ideas y folklore de Eusebio Dojorti (Buenaventura Luna).” Studies in Latin American Popular Culture, vol. 24 (2016): 242-271. https://doi.org/10.7560/SLAPC3412.

Canción Protesta, no.1 (1968).

Carlson, Julius Reder. “The 'Chacarera Imaginary': 'Santiagueñan’ Folk Music and Folk Musicians in Argentina." Ph.D. diss. UCLA, 2011.

Chamosa, Oscar. The Argentine Folklore Movement: Sugar Elites, Criollo Workers, and the Politics of Cultural Nationalism, 1900-1955. Tucson: The University of Arizona Press, 2010. 
Clonrozier, Patrick. “Atahualpa Yupanqui.” Accessed August 2, 2019. www.atacris.com.

Denisoff, R. Serge, and Richard A Peterson, eds. The Sounds of Social Change. Chicago: Rand McNally Sociology Series, 1972.

Eyerman, Ron, and Andrew Jamison. Music and Social Movements: Mobilizing Traditions in the Twentieth Century. Cambridge, UK: Cambridge University Press, 1998. https://doi.org/10.1017/CBO9780511628139.

Fernández Retamar, Roberto. "Caliban: Notes Toward a Discussion of Culture in Our America." In Caliban and Other Essays, trans. Edward Baker, 2-46. Minneapolis: University of Minnesota, 1989.

Flores, Schubert, and Héctor García Martínez. Hombres y caminos: Yupanqui, afiliado comunista. Córdoba, Argentina: Editorial Fundación Ross, 2012.

Fornaro, Marita, and Fabricia Malán. "Protesta, siempre: una panorama y tres casos uruguayos." Boletín Música, no. 45 (2017): 41-71.

Franco-Lao, Méri. Basta! Canciones de testimonio y rebeldía de América Latina. México D.F.: Biblioteca ERA, 1967 (1970).

Frith, Simon. Performing Rites: On the Value of Popular Music. Cambridge, MA: Harvard University Press, 1996.

Galasso, Norberto. Atahualpa Yupanqui: El canto de la patria profunda. 4th ed. Buenos Aires: Ediciones del Pensamiento Nacional, 2013.

Kaliman, Ricardo. Alhajita es tu canto: El capital simbólico de Atahualpa Yupanqui. Córdoba, Argentina: Editorial Comunicarte, 2004.

Karush, Matthew B. Musicians in Transit: Argentina and the Globalization of Popular Music. Durham, NC: Duke University Press, 2017. https://doi.org/10.1215/9780822373773.

Luna, Félix. Atahualpa Yupanqui. Madrid: Ediciones Jucar, 1974.

Molinero, Carlos, and Pablo Vila. "Atahualpa Yupanqui: The Latin American Precursor of the Militant Song Movement." In The Militant Song Movement in Latin America: Chile, Uruguay, and Argentina, edited by Pablo Vila, 163-193. New York: Lexington Books, 2015.

Molinero, Carlos D. Militancia de la canción: Política en el canto folklórico de la Argentina (1944/1975). Buenos Aires: Ediciones De Aquí a la Vuelta, 2011.

Orquera, Fabiola. "From the Andes to Paris: Atahualpa Yupanqui, the Communist Party, and the Latin American Folksong Movement." In Red Strains: Music and Communism Outside the Communist Bloc, edited by Robert Adlington, 105-119. Oxford: Oxford University Press, 2013. https://doi.org/10.5871/bacad/9780197265390.003.0009.

—. "Marxismo, peronismo, indocriollismo: Atahualpa Yupanqui y el norte argentine." Studies in Latin American Popular Culture, no. 27 (2008): 1-21.

Pellegrino, Guillermo. Las cuerdas vivas de América. Buenos Aires: Editorial Sudamericana, 2002.

Pintos, Víctor, ed. Cartas a Nenette. Buenos Aires: Editorial Sudamericana, 2001.

Pujol, Sergio. En nombre del folclore: Biografía de Atahualpa Yupanqui. Buenos Aires: Emecé Editores, 2008.

Reyes Matta, Fernando. "The New Song and Its Confrontation in Latin America." In Marxism and the Interpretation of Culture, edited by Cary Nelson and Lawrence Grossberg, 447-460. Urbana and Chicago: University of Illinois Press, 1988. https://doi.org/10.1007/978-1-349-19059-1 32. 
Rios, Fernando. "La Flûte Indienne: The Early History of Andean Folkloric-Popular Music in France and Its Impact on Nueva Canción.” Latin American Music Review, vol. 29, no. 2 (2008): 145-189. https://doi.org/10.1353/lat.0.0022.

Spener, David. We Shall Not Be Moved/No nos moverán: A Biography of a Song of Struggle. Philadelphia: Temple University Press, 2016. https://doi.org/10.26530/OAPEN_605458.

Urtizberea, Manuel. Don Ata: La voz de un continente. Buenos Aires: Editorial Marea, 2017.

Vaughan, Alden and Virginia Mason Vaughan, Shakespeare's Caliban. A Cultural History. New York: Cambridge University Press, 1991.

Viglietti, Daniel. "La canción popular." La del taller: Revista de los talleres de latinoamericanos de música popular, no. 7 (1986): 7-11.

Walser, Robert. Running with the Devil: Power, Gender, and Madness in Heavy Metal Music. Middletown, CT: Wesleyan University Press, 1993. 


\section{Acknowledgements}

This article would not have been possible without the support of Mount Saint Mary's University, Los Angeles, the inspiration of Andréa Falcão, Rodrigo Torres Alvarado, and Manuel Vilches Parodi, and the feedback provided at conferences including Instrument of Change: The International Rise of the Guitar (2016), SEM (2017), and ICTM LatCar (2018). Special thanks to Kristi Brown-Montesano, Natalia Bieletto Bueno, Patrick Clonrozier, Shabnam Fasa, Jennie Gubner, Eric Johns, Raymond Knapp, Claudia Macdonald, Elijah Wald, and Nolan Warden for their proofreading and suggestions. 